\title{
Archipel
}

ARCHIPEL Études interdisciplinaires sur le monde insulindien

99 | 2020

Varia

\section{Buru Island: Still Much More to Reveal}

\section{Vannessa Hearman}

\section{(2) OpenEdition \\ Journals}

Electronic version

URL: http://journals.openedition.org/archipel/1651

DOI: 10.4000/archipel. 1651

ISSN: 2104-3655

\section{Publisher}

Association Archipel

\section{Printed version}

Date of publication: 15 July 2020

Number of pages: 29-33

ISBN: 978-2-910513-83-2

ISSN: 0044-8613

\section{Electronic reference}

Vannessa Hearman, "Buru Island: Still Much More to Reveal", Archipel [Online], 99 | 2020, Online since 02 June 2020, connection on 15 March 2021. URL: http://journals.openedition.org/archipel/1651 ; DOI: https://doi.org/10.4000/archipel.1651 


\section{Buru Island: Still Much More to Reveal}

Pulau Buru: Tanah Air Beta (Buru Island: My Home)

Documentary, 40 min., 2016

Director : Rahung Nasution

Producers : Whisnu Yonar and Dolorosa Sinaga

Production : Beranda Rakyat

Distributed via buttonijo.com

Language : Indonesian with English subtitles

Buru Island: My Home follows the journey of former detainees, Hersri Setiawan and Tejabayu Soedjojono to the island in the Moluccas that was used by the Indonesian New Order regime as a prison site. They meet old friends, visit the graves of those who have passed away and tell their part of the island's history.

Hersri, a writer, was a member of the People's Cultural Institute (Lekra, Lembaga Kebudayaan Rakyat), a leftist cultural group that was linked to the Indonesian Communist Party. Tejabayu was a student activist in the organisation CGMI (Concentrasi Gerakan Mahasiswa Indonesia, Indonesian Student Movement Centre) at the prestigious Gadjah Mada University in Yogyakarta, Indonesia. The two are reasonably well-known publicly as former detainees, Hersri in particular, who has written several books about his experiences on Buru Island. Making use of his creative works, the film

1. Senior lecturer, Charles Darwin University, Australia. 
features a few of his poems as a voiceover and text on screen, evoking island life under the barrel of a gun.

The Indonesian government transported and detained about 12,000 men from Java from the time Buru was first used as a place of detention in 1969 until their release in 1978. The camp's most famous resident was Pramoedya Ananta Toer, who, like Hersri, was a writer and a member of Lekra. Works by former detainees and Lekra writers were banned by the government after the 1965 suppression of the Communist Party. Those sent to Buru Island from 1969 onwards by the army-dominated government led by President Suharto came from all walks of life ; the one factor that united them was their actual or suspected links with the PKI and leftist mass organisations.

The film opens with a domestic scene of Hersri making himself a hot drink in his home and then listening to a cassette and looking at some notebooks. Shortly after President Suharto resigned in May 1998, which ushered in democratisation for Indonesia, Hersri travelled to several countries where he collected hundreds of interviews with Indonesians exiled abroad as a result of their differences with the New Order regime. Perhaps the cassette was the result of one such interview, although the filmmakers do not make this clear to the viewer.

The film opens with mention of ' 30 September 1965' and refers to a genocide and 'survivors of crimes of humanity', but does not provide further explanation. On 30 September 1965, a group of army officers and soldiers calling themselves the 30 September Movement abducted and killed six generals and a lieutenant, including the highest echelon of leadership of the Indonesian Army. Major-General, later President, Suharto led a violent suppression campaign of this group and the PKI that Suharto alleged was the mastermind of the group. The suppression of the PKI resulted in the killing of half a million members and sympathisers of the party by the army and civilian militias. About 600,000 to three-quarters of a million Indonesians were also detained, mostly without trial, including those on Buru. The Suharto regime, over its 32 years in office, carefully restricted discussions about the army's actions to gain power from President Sukarno in those tumultuous years of 1965-1966. By restricting the ability of writers like Hersri to communicate their experiences following their incarceration, the regime ensured that its version of history, provided in the school curriculum and in popular media, was easily transmitted to younger generations born many years after these events.

It is this painful work of re-weaving connections with the younger generation and re-establishing contact with the places and people of Buru that the film is preoccupied with showing. Transmigrants, namely settlers from other parts of Indonesia, and indigenous people also live on Buru. The island is facing environmental problems from gold mining on the adjacent island 


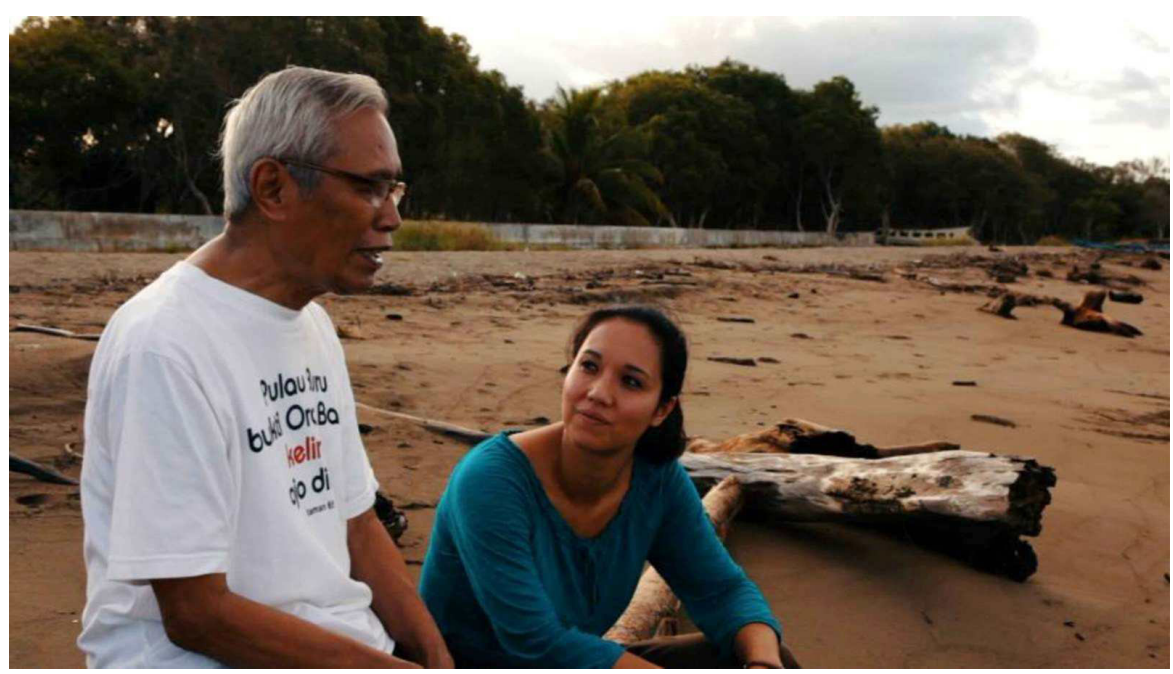

Hersri Setiawan and his daughter, Ken Setiawan.

of Sulawesi. Hersri undertakes his journey back to Buru also with his wife, activist Ita Nadia, and daughter, Ken Setiawan, an academic at the University of Melbourne, who herself writes and publishes on the 1965 issue. The film crew follows their journey by land and sea to find those former detainees Hersri knew who chose to remain, and to revisit some sites of significance to detainees. There is rich potential here for exploring how the family negotiates a difficult and mysterious past, given for many younger people, it has been difficult to unearth family histories that entail connections with the 1965 cataclysm. In a poignant scene, the three stand together, while Hersri recounted his early life, including his leadership of a poetry reading association in Yogyakarta and his subsequent placement with the Afro-Asian Writers' Bureau office in Colombo, then-Ceylon in the early 1960s.

The film's 'fly-on-the-wall' observational style lends an intimacy to the scene above as we observe the three. In several parts of the film, the bond between Hersri and his daughter Ken is readily apparent and made explicit most frequently by Ken's statements to Hersri's former fellow detainees about her feelings of being on the island, with meeting them, and in retracing Hersri's steps with him. However, we do not gain much further insight into the relationship between father and daughter. Similarly, Hersri's conversations with other former detainees on the island about Indonesian politics lack context, and therefore are obscure for the viewer.

In visiting the sites of memory on the island, those places that marked and recalled incarceration, we see a refurbished cultural hall where detainees 
used to perform, a modest monument marking the village established in line with the prison camp, Savanajaya, and the grave of one of his closest friends while in exile, Heru Santoso. The movie does not explain the significance of this particular site. ${ }^{2}$ Heru was a leader of the CGMI student organisation in Surabaya, East Java, and had tried to convince Hersri to make an escape attempt from the island. According to one former exile, Heru died from hepatitis in the camp hospital. ${ }^{3}$

Regrettably, there is also little explanation here about the sites other than what is voiced by the interlocutors on screen. Without adequate 'setting up' and organisation of information by the filmmakers, the significance of these sites is not transmitted adequately to the viewer. For example, a scene where prayers are recited by the group, led by a Father, Baskara (who was not introduced in the film), beside Heru's neglected grave could have been even more poignant, had we understood something about the deceased.

This film provides glimpses of Buru Island, a relatively remote part of Indonesia and the return of men who had years of their lives taken by a faraway ruling regime by being placed there. They returned as free men who are still haunted by memories of those they left behind. This is surely a powerful premise for a documentary. Contrasting with other documentaries which provide more contextualization through interviews and archival images, the director chose to follow the men to Buru without providing background information about the key dramatis personae and the events that impacted their lives. The film may pose some difficulties for viewers who have little knowledge about Indonesian history, in particular, the history of the Indonesian Left and its destruction by the army in 1965. The observational style leaves the viewer wondering about some of the organisations and individuals mentioned in Hersri's narrative, about which the film does not provide much explanation. In using mainly impromptu observation as its chief technique, the resulting footage contains many narrative gaps. Owing to the technique chosen - the absence of active intervention such as the addition of interviews and tighter editing, and the lack of context and information provided -, it would be hard for younger Indonesians, the film's purported target audience, to follow the narrative thread in this film fully and to develop more knowledge about the anti-communist violence of $1965-66 .{ }^{4}$ There continues to be disinformation and confusion in Indonesia and internationally about these events, including

2. Hersri Setiawan, Diburu di Pulau Buru, Yogyakarta: Galang Press, 2006, p. 194.

3. Anonymous, 'At Australia Bridge', in Baskara T. Wardaya S. J (ed.), Truth Will Out: Indonesian accounts of the 1965 mass violence, translated by Jennifer Lindsay, Clayton, Vic.: Monash University Publishing, 2013, p. 301.

4. See comment by Whisnu Yonar in Ika Krismantari, 'Documentary Provides Different Angle on 1965 Tragedy', The Jakarta Post, 19 March 2016, https://www. thejakartapost.com/news/2016/03/19/documentary-provides-different-angle-1965tragedy.html 
the phenomenon of long-term imprisonment, Indonesia's major human rights issue of the 1970s. While the film contributes somewhat to our historical knowledge, there continues to be many unexplored possibilities in telling the story of Buru. The survivors of this gross human rights violation are diminishing in number and to tell their stories powerfully and meaningfully would contribute significantly to addressing this past. 
